\title{
Örgütlerde Stres Kaynaklarının Çalışanların İş-Aile Çatışması Üzerine Etkisi
}

\section{Özet}

\author{
Recep KILIÇ* \\ Sibel ÖZAFŞARLIOĞLU SAKALLI*
}

İş ve aile kavramları, insanların yaşamlarında en fazla önem verdikleri iki ayrı alanı temsil etmektedir. Günümüz iş yaşamına etki eden faktörlerden birisi de çalışanların iş ve aile yaşamları arasında yaşadıkları çatışmalardır. İş stresi çalışanların, performans, verimlilik, iş tatmini, sağlık ve sosyal ilişkiler açısından kritik bir öneme sahiptir. Bu çalışma şeker fabrikası çalışanlarının, iş stresi faktörleri ile iş-aile çatışması arasındaki ilişkilerin belirlenmesi amacıyla yapılmıştır. Aynı zamanda ilgili değişkenler ile sosyo-demografik değişkenler arasındaki ilişkiler de araştırma kapsamında incelenmiştir. Çalışmada anket tekniği kullanılmıştır.

Araştırma sonucunda iş stresi faktörleri ile iş-aile çatışması arasında düşük ve negatif bir ilişki, iş stresinin faktörleri olan iş kontrolü ve sosyal destek arasında ise pozitif ve anlamlı ilişkiler gözlenmiştir. Çalışanların iş sorumluluklarının aile yaşantısını etkilemediği görülmektedir. Ayrıca çalışanlar en fazla sosyal destek ile ilgili maddelerden memnun olduklarını ifade etmektedirler. Demografik değişkenler açısından cinsiyet, medeni durum, yaş, gelir, çocuk sayısı ile iş stresi faktörleri ve iş-aile çatışması arasında herhangi bir farklılık yoktur. Üç vardiyalı çalışanlar, daimi gündüz çalışanlara nazaran daha fazla iş-aile çatışması yaşamaktadır. Memurların işçilere nazaran daha fazla karar verme hakkının ve iş yükünün olduğu görülmüştür. Eğitim değişkeni açısından ise ilköğretim mezunlarının üniversite mezunlarına nazaran daha az karar verme hakkında sahip olduğu tespit edilmiştir.

Anahtar Kelimeler: Stres, İş Stresi, İş-Aile Çatışması.

\footnotetext{
* Yrd.Doç.Dr., Balıkesir Üniversitesi Bandırma İ.İ.B.F. İşletme

** Öğr. Gör., Uşak Üniversitesi Karahallı MYO İktisadi ve İdari Programlar
} 


\title{
The Influence Of Stress Sources In Organizations On The Work- Family Conflict Of Employees
}

\begin{abstract}
Work and family are the two concepts that people give importance utmost importance in their lives. One of the factors that influence today's work lives is the conflict employees have between their family lives and work lives. Work stress has a critical place in terms of the performance, productivity, job satisfaction and social relations of employees. This study was conducted among sugar factory employees to examine the relations between work stress factors and work- family conflict. Besides, the relations between the variables in question and socio-economic variables have also been studied. Questionnaire technique was used for the study.

The result of the study shows that there is a low and negative relation between work stress factors and work- family conflict; positive and meaningful relations between work control and social support, factors of work stress. It is seen that the work responsibilities of employees do not affect their family lives. Moreover, the employees state that they are content with social support items the most. There is no difference between work stress and work- family conflict in terms of demographic variables, gender, marital status, age, income and number of children. Those working three shifts have relatively more workfamily conflict when compared with those working day shift on a permanent basis. It is seen that the civil servants have more decision- making rights and workloads than do the workers, as to the education variable, elementary schools graduates have fewer decision- making rights than do university graduates.
\end{abstract}

Key words: Stress, Work Stress, Work- Family Conflict.

\section{1- GíRiş}

Günümüzde organizasyonlar ve çalışanlar, hızla değişen ve belirsizliğin hakim olduğu zorlu bir rekabet ortamı içindedir. Yoğun rekabetin yaşandığı küresel çalışma yaşamında organizasyonlar varlıklarını sürdürebilmek için her 
zamankinden daha fazla etkin ve verimli olmak zorundadır. Değişime uyum çabasının bir sonucu olarak stres, insanların hayatında yaşamın ayrılmaz bir parçası olarak yer edinmiştir (Baltaş, 2002: 14). Bu nedenle de stres bireylerin yabancı olmadıkları bir kavramdır. Organizasyonlar sürdürülebilir rekabet gücü yakalamak için çeşitli enstrümanları kullanarak verimliliklerini arttırmaya çalışmaktadır. Bu çabanın temelinde bireysel ve örgütsel performans faktörü stratejik yönetim sürecinin her aşamasında yer almaktadır. Bu sorunsalın en önemli değişkenlerinden birisi performansın ana aktörü olan "insan" faktörüdür. Bu koşullarda insanları stressiz düşünmek mümkün değildir. Stres yaratan faktörler, bireyin kontrol altına alamayacağı nitelikte ise bireyin ortama uyum göstermesi zorlaşmaktadır. Stres, bireyde gerilim yaratıp sağlık sorunlarının artmasına, motivasyon kaybına dolayısıyla performansının düşmesine yol açtığ1 gibi sonuçta örgütsel yapı ve işleyişi üzerinde de verimin düşmesine neden olmaktadır.

İş bireyler için önemlidir. İş bireyler için gelir kaynağı olduğu gibi aynı zamanda kendilerini gerçekleştirme imkanı da sunmaktadır. Bu durum Maslow'un ihtiyaçlar hiyerarşisi kuramını da destekler niteliktedir. İnsanlar yaşamlarının büyük kısmını işte geçirmektedirler. Bu durum ister istemez çalışanın iş yaparken ya da iş sonucunda oluşan fiziksel ve psikolojik etkenlere maruz kalmasına neden olmaktadır (Soysal, 2009a: 334). Bu maruz kaldığ1 etkenlerin her biri örgütsel stres kaynağıdır.

Örgütsel stres işyerindeki herkesi etkiler. Kişilerin ne yaptığı ya da hangi ortamdan geldiği fark etmez. İş yerindeki stres bireylerin sağlığını, esenliğini ve evdeki hayatının kalitesini etkiler (Losyk, 2006: 18). Çalışma saatlerinin düzensizliği, vardiyalı çalışma sistemi, rol belirsizliği, rol çatışması, iş güvenliğinin olmayışı, aşırı ya da az iş yükü, ücretin yetersiz olması, çalışma ortamından kaynaklanan fiziksel etmenler gibi çok sayıda faktör çalışanlar üzerinde olumsuz etkilere sahip olmakta, onların sağlıklarını tehdit etmektedir. Çalışanlar için stres bir seviyeye kadar onların performanslarını arttırıcı etki yapmakta ancak optimal seviyeyi aşması durumunda ise kişinin performansını düşürmektedir.

Çalışan için iş önemli olduğu kadar diğer önemli olan bir alan da ailedir. Bu iki alanın da bireyden birtakım beklentileri vardır. Ancak bu 
beklentiler her zaman birbiriyle uyumlu olmamakta ve eş zamanlı olarak ortaya çıkabilmektedir. $\mathrm{Bu}$ nedenle çalışan iki alanı dengeleme konusunda zorlanmaktadır. Bir tarafın taleplerini karşılarken diğer tarafı ihmal etmek zorunda kalmakta ya da daha az zaman ayırmak durumda olmaktadır. Bu şekilde işin ailenin sorumluluklarını engellemesi iş-aile çatışmasına neden olurken ailenin işin sorumluluklarını, görevlerini yerine getirmesine engel olması ise aile-iş çatışmasıdır.

Çalışanlar ailelerine, çocuklarına daha çok zaman ayırmak istedikleri için işten gelen her talep strese neden olmaktadır. Çünkü işe ayrılacak zamanın artması aileye ayrılacak zamanı azaltmaktadır. Aynı zamanda işteki yorgunluk, gerginlik eve yansıyabilmektedir. Örgütlerde strese neden olan faktörlerin tespit edilmesi meydana gelebilecek olumsuzluklara yönelik önceden gerekli önlemlerin alınmasına katkıda bulunacaktır.

$\mathrm{Bu}$ çalışma örgütlerde stres kaynaklarının çalışanların iş-aile çatışması üzerindeki etkisini incelemeyi amaçlamaktadır. Bu amaçla makalenin kuramsal çerçeve bölümünde literatür kaynaklarından yararlanarak stres kavramı tanımlanmış ve stresin ortaya çıkmasına neden olan stres kaynaklarına yer verilmiştir. İş yaşamındaki stresin çalışanların iş-aile çatışması üzerindeki etkisini inceleyen çalışmalar yine bu bölümde ele alınmıştır. Çalışmanın metodoloji kısmında ise, araştırmanın amacı ve yöntemi açıklanarak, araştırma sonucu elde edilen veriler analiz edilmiş ve bulgular yorumlanmıştır.

\section{2- KURAMSAL ÇERÇEVE}

\subsection{Stres ve Stres Kaynakları}

Stres tanımlanması çok kolay olmayan karmaşık kavramlardan biridir. Buna binaen de stresle ilgili birçok tanım vardır (Baltaş ve Baltaş, 1990: 29; Bingöl ve Naktiyok, 2001:323; Torun, 1997: 43; Dinçer, 1994: 219; Eren, 1998: 223; Barutçugil, 2002: 144; Hughes \& Boothroyd, 2002: 11). Stres kelimesinin kökeninde duygularla savaş vardır (Bingöl ve Naktiyok, 2001:323). İş yaşamında temel bir sorun olan stres (Örücü ve Demir, 1999: 59), insanların mutsuz bir yaşam sürmelerine neden olan etkenlerin başında gelmektedir. Eren (1998:223)'e 
göre stres, bireyler üzerine etki yapan ve onların davranışlarını, iş verimini ve başka insanlarla ilişkilerini etkileyen bir kavramdır. Hughes ve Boothroyd (2002: 11)'a göre stres, bireyin duygusal ya da fiziksel durumuna karşı olası bir tehdit sezdiğinde vücudunda ya da beyninde oluşan tepkidir. Stres, organizmanın fizik ve ruhsal sınırlarının zorlanmasıyla ortaya çıkan bir durumdur (Baltaş ve Baltaş,1990: 29). Stresin uzun sürmesi ya da aşırı olması halinde, bireyin fizik ve ruh sağlığına zararlı etkileri olabileceği kabul edilmektedir (Ertekin, 1993; 5). Kalabalık, gürültülü ve aşırı trafik yoğunluğunun bulunduğu büyük şehirlerde yaşayan bireylerin stresten etkilenme düzeyleri de diğer bireylere nazaran daha yüksektir. İş yaşamının insana yüklediği sorumlulukların her geçen gün biraz daha artması, bireylerin strese karşı geliştirdikleri savunma mekanizmaları konusunda hassasiyetlerini biraz daha artırmaktadır (Güçlü, 2001:101).

İş stresi veya mesleki stres olarak da adlandırılan örgütsel stres, örgütle ya da işle ilgili olarak herhangi bir beklentiye karşı bireysel enerjinin harekete geçmesi olarak tanımlanmaktadır (Pehlivan, 2000: 21). Işıkhan (2001: 27) ise örgütsel stresi, bireyi normal fonksiyonlarından saptıran psikolojik ve/veya fiziksel davranışlarını değiştiren işle ilgili etmenlerin sonucunda oluşan psikolojik durum olarak tanımlamaktadır. Örgütsel stres, kişi ve iş ilişkilerinden doğan ve insanı normal işlevlerinden alıkoyan değişiklikler getiren bir durumdur (Akgündüz, 2006: 24).

Stres kaynakları hakkında araştırma yapan bilim adamlarının benzer saptamalar yaptıkları görülmektedir. Aralarındaki farklar genellikle stres kaynaklarının gruplandırılması konusunda ortaya çıkmaktadır. Benzer stres kaynaklarının farklı başlıklar altında toplanması dikkatleri çekmektedir. Stres kaynakları; genel yapısı itibariyle örgüt dışı stres kaynakları, örgütsel stres kaynakları ve kişisel stres kaynakları çatısı altında toplanmaktadır. Örgüt dışı stres kaynaklarında genel olarak üç faktör ön plana çıkmaktadır; aile, sosyolojik değişiklikler ve mali problemler (Gökdeniz, 2005:173). Örgütsel Stres Kaynakları (Özmutaf, 2006:75-81; Baltaş-Baltaş, 2000: 59; Luthans, 1992:404; Bratton-Gold, 1999: 145) işle ilgili nedenler (işin az veya çok olması), çalışanın örgüt içindeki rolü ile ilgili nedenler (rol belirsizliği), kişilerarası ilişkilerden doğan nedenler ( yöneticilerle ve diğer çalışanlarla olumsuz ilişkiler), kariyer gelişimi ile ilgili nedenler ( aşırı yükselme veya yükselememe, iş güvenliği eksikliği), örgüt yapısı ile ilgili nedenler ( kararlara katılımın kısıtlanması, iletişim kanallarının 
iyi kurulmaması, ücret vb. konularda yanlış politikaların uygulanması) den kaynaklanmaktadır. Kişisel Stres Kaynakları ise çalışanın kişisel yaşamından kaynaklanan evlilik ve çocuklarla ilgili sorunlar, ölüm, boşanma, hastalık, hamilelik, ekonomik sorunlar, orta yaş bunalımı, yaşam tarzındaki değişiklik gibi faktörlerdir.

Strese yol açan faktörleri de fiziksel ve duygusal olarak sınıflandırmak mümkündür (Erdoğan, 1999: 279-280). Duygusal strese yol açan faktörler her şeyden önce kişiseldir. Kişinin kendi düşünce aleminde kendi kendine meydana getirdiği kuruntular bu kapsamda değerlendirilebilir. Fiziksel stres sebepleri ise, kişileri daha ziyade bedensel olarak etkileyen dişsal faktörlerdir. Bireyin yaşadığı veya çalıştığı ortamın aşırı soğuk veya sıcak olması, yeteri kadar aydınlatılmaması, aşırı gürültü vb. faktörlerdir.

Stresin birey ve örgüt üzerinde çeşitli etkileri ve sonuçları mevcuttur (Taşlıyan ve Güven, 2006: 208). Birey üzerindeki etkileri fizyolojik ve psikolojik olmak üzere iki grupta sınıflandırmak mümkündür. Fizyolojik etkiler, dolaşım sistemi, kalp ve damar hastalıkları, üreme sistemi hastalıkları, deri hastalıkları, migren vb. rahatsızlıklar strese bağlı fizyolojik rahatsızlıklardır. Psikolojik etkiler ise kayg1, depresyon, uykusuzluk ve psikolojik yorgunluklar gibi stres sonucunda bireylerde ortaya çıkan psikolojik rahatsızlıklardır. Stresin örgüt üzerindeki etkilerini ise öncelikle ekonomik olarak verim düşüusü, yabancılaşma, iş kazalarının artması ve kalifiye iş gücü kayıpları şeklinde görülecektir.

Özet olarak aşırı stres, hem psikolojik, hem de fiziksel rahatsızlıklara yol açacağından performansın düşmesinde etkili bir faktör olarak karşımıza çıkmakta ve işgörenin içinde bulunduğu örgütün verimini olumsuz yönde etkilemektedir.

\section{2. İş-Aile Yaşam Çatışması}

Bireyler için zorlayıcı bir yaşantı olan iş-aile çatışması örgütsel davranış alanında önemsenen bir kavram olup oldukça da incelenen bir konu olmuştur (Turgut, 2011; Efeoğlu, 2006; Turunç ve Çelik, 2010; Yurtseven, 2008; Turunç ve Erkuş, 2010 ; Çetinkaya, 2011). İş-aile yaşam çatışması, çalışanların aynı anda birden fazla role sahip olması ve bu rollerin birbirleri ile çatışmasından ortaya 
çıkmaktadır (Dubrin,1997:116). İş aile yaşam çatışması roller arası bir çatışma biçimidir. $\mathrm{Bu}$ çatışma biçiminde bir alandaki yükümlülüklerin yerine getirilmesiyle ilgili yaşanan baskıların diğer alandaki yükümlülüklerin yerine getirilmesini güçleştirmesi söz konusudur (Greenhaus ve Beutell, 1985: 77). Bu roller arasındaki çatışma iki yönlüdür (Gutek, Searle ve Klepa, 1991: 560-68 ). İş rollerinin, aile sorumluluklarının yerine getirilmesini engellediğinde yaşanan çatışma 'İş-Aile Çatışması' (İAÇ) olarak; aile rollerinin, işle ilgili sorumlulukların yerine getirilmesini engellediğinde yaşanan çatışma 'Aile-İş Çatışması' (AİÇ) olarak isimlendirilir. (Frone ve Cooper, 1992: 728; Voydanoff, 2005: 708). Konu ile ilgili yapılan araştırmalar; iş-aile çatışmasının, aile-iş çatışmasından daha fazla yaşandığını ortaya koymaktadır (Kinnunen vd., 2004; Frone ve Cooper, 1992; Netemeyer, Boles ve McMurrian,1996). Bu yöndeki bulgular gerekçesiyle bu araştırmada iş-aile çatışması ele alınmıştır.

\section{3. Örgütsel Stres Kaynakları ve İş-Aile Çatışması Arasındaki İlişki}

Günümüz iş dünyasında bireysel anlamda stres kaynaklarının yanı sıra örgütsel anlamda da bireyi baskı altında tutan ve iş stresini artıran çeşitli örgütsel stres kaynakları bulunmaktadır. Çalışanın iş stresi düzeyini azaltan ya da arttıran unsurlardan birisi de çalışanın yakın çevresinden gördüğü sosyal destek olduğu dikkate alınmaktadır. Sosyal destek birinin diğerine yardım edip onun mutluluğunu arttırdığı kişilerarası stres azaltıcı bir kaynaktır (Wallace, 2005: 514). Bu yaklaşıma göre, sosyal destek kaynağı olarak aile, iş stresi üzerinde etkili olabilecektir. Çalışanın iş yerinde yaşadığı stres sadece iş yaşamını değil, iş-aile yaşamını da etkileyecek dolayısıyla iş-aile çatışması yaşamasına neden olacaktır (Wallace, 1999).

Bazı araştırmacılar tarafından yapılan çalışmalarda çalışanın iş stresi düzeyinin iş aile çatışması düzeyini etkileyeceği belirlenmektedir. (Netenmeyer vd., 2004; Vinokur vd., 1999; Karatepe ve Baddar, 2006). Çalışanların işinde meydana gelen olumlu yada olumsuz gelişmelerinde aile yaşamını etkilediği tespit edilmiştir (Burke, 1986; Leiter \& Durup, 1996; Netenmeyer vd., 2004).

Carlson ve Karatepe'nin çalışmasında sık sık tekrarlanan fazla mesailerin, vardiyalı çalışma şeklinin, tatilde ve hafta sonu çalışmanın, günde 
dokuz saati aşan çalışmaların, iş-aile çatışmasıyla pozitif yönde ilişkili olduğunu tespit etmiştir (Carlson vd., 1995: 18; Karatepe ve Baddar, 2006).

\section{3- YÖNTEM}

\subsection{Araştırmanın Amacı}

$\mathrm{Bu}$ çalışmanın temel amacı kamu sektöründe faaliyet gösteren çalışanların stres kaynakları ile iş-aile yaşam çatışmasının boyutlarından biri olan iş-aile çatışması arasındaki ilişkileri incelemektir. Bu bağlamda çalışanların en çok yaşadıkları stres faktörleri belirlenecektir. Bunun yanında çalışanların yaşadığı stres faktörlerinin iş-aile çatışması üzerindeki etkileri de belirlenecektir.

\subsection{Araştırmanın Kapsamı}

$\mathrm{Bu}$ çalışmanın evrenini Uşak ilinde faaliyet gösteren bir kamu sektöründe çalışan 440 çalışan oluşturmaktadır. 440 kişilik bir evren için 205 kişilik bir örneklemin yeterli olduğu tespit edilmiştir (Altunışık vd., 2010:135). 205 kişiye anket ulaştırılmış ancak 148 anket geri dönmüştür. Bu anketlerin belirli bir kısmı yeterli veri ve anlamlılığa sahip olmadığı için toplam 136 anket formu değerlendirmeye tabi tutulmuştur.

\subsection{Araştırmanın Yöntemi}

Araştırmada veri toplama tekniği olarak anket yöntemi kullanılmıştır. Anket formunun birinci bölümünde çalışanların sosyo-demografik özelliklerini tespit etmeye yönelik sorular bulunmakta ve bu bölümde toplam 8 (cinsiyet, yaş, medeni durum, eğitim durumu, mevcut işyerindeki çalışma süresi, aylık geliri, çalışma şekli ve pozisyonu) soru yer almaktadır.

Anketin ikinci bölümünde, “İsveç İş Yükü- İş Kontrolü- Sosyal Destek Ölçeği" yer almaktadır. Demiral ve arkadaşları (2007) tarafından Karasek (1979)'in iki boyutlu İş talep-kontrol modeline sosyal destek boyutunun eklenmiş halidir. Cevaplar 5'li likert ölçeği ile alınmıştır (1=Hiç Memnun Değilim, 5=Çok Memnunum). İsveç İş Yükü- İş Kontrolü- Sosyal Destek Ölçeği, iş stresi ile ilgili 17 sorudan oluşmaktadır. Ölçeğin üç ana alt bölümü vardır. İş 
yükü için 5, iş kontrolü için 6 ve sosyal destek için 6 soru içermektedir. İş kontrolünün ölçümünde kullanılan 6 sorudan ilk dördü beceri kullanımı, diğer ikisi karar serbestliği alt başlıklarından oluşmaktadır. Bu çalışmamızda iş stresi anketinin Cronbach alfa değeri $0.867^{\prime}$ dir. Bu değer daha önce yapılan çalışmalar incelendiğinde son derece güvenilir bir değerdir (Demiral vd., 2007; Çetinkaya, 2011; Wallace, 2005).

Anket formunun üçüncü bölümünde ise "İş-Aile Yaşam Çatışması Ölçeği" kullanılmıştır. Çalışanların iş-aile yaşam çatışması düzeylerini ölçmek üzere Netenmeyer ve arkadaşları (1996) tarafından geliştirilen iş-aile yaşam çatışması ölçeği kullanılmıştır. Ölçek, çalışanların iş yaşamından kaynaklanan işaile çatışması ve aile yaşamından kaynaklanan aile-iş çatışması düzeylerini ölçmeyi amaçlayan iki alt boyuttan oluşmaktadır. Ölçekte her iki boyuta ilişkin beşer madde bulunmaktadır. Konu ile ilgili yapılan araştırmalar; iş-aile çatışmasının, aile-iş çatışmasından daha fazla yaşandığını ortaya koymaktadır (Kinnunen vd., 2004; Frone ve Cooper, 1992; Netemeyer, Boles ve McMurrian,1996). Bu yöndeki bulgular gerekçesiyle bu araştırmada iş-aile çatışması ele alınmıştır. Cevaplar 5'li likert ölçeği ile alınmıştır (1=Kesinlikle katılmıorum, 5=Kesinlikle katılıyorum). Netenmeyer ve arkadaşları (1996) tarafından yapılan güvenilirlik analizleri sonucunda iş-aile çatışması boyutlarının Cronbach alfa güvenilirlik katsayıları 0.88 olarak tespit edilmiştir. Ölçek Türkçe'ye Efeoğlu (2006) tarafından çevrilmiştir. Yapılan çalışmada güvenilirlik analizleri sonucunda ölçeğin toplam Cronbach alfa güvenilirlik katsayısı 0.910, iş-aile çatışması boyutunun 0.878 olarak bulunmuştur. Bu değer daha önce yapılan çalışmalar incelendiğinde son derece güvenilir bir değerdir (Turunç ve Çelik, 2010; Turunç ve Erkuş, 2010; Efeoğlu, 2006).

\subsection{Hipotezler}

Hipotez 1: Çalışanların iş stresi boyutları ile iş-aile çatışması arasında pozitif ve anlamlı bir ilişki vardır.

Hipotez 2: Çalışanların sosyo-demografik özellikleri ile iş stresi ve işaile çatışması arasında anlamlı bir farklılık vardır.

Hipotez 3: Çalışma şekli ile iş-aile çatışması arasında anlamlı bir farklılık vardır.

Hipotez 4: Çalışanların iş stresi düzeyleri arttıkça iş-aile çatışması da artmaktadır. 
Uşak Üniversitesi Sosyal Bilimler Dergisi

$2013,6 / 3$

R. KILIÇ, S. Ö. SAKALLI

\section{4- BULGULAR}

Anket verileri SPSS(Statistical Package for the Social Science) programı yardımıyla araştırma faktör analizi, güvenilirlik analizi, $t$ testi, ANOVA, korelasyon ve regresyon gibi istatistiki teknikler kullanılarak analiz edilmiştir.

Araştırmanın genel amacı çerçevesinde toplanan verilerden istatistiksel çözümlemeler sonucu elde edilen bulgular bu bölümde verilmektedir. Bulguların sunuluşunda öncelikle araştırma grubunun genel yapısını tanıtıcı istatistiksel dağılımlara yer verilerek diğer bulgular araştırmanın amaçları ve bu amaçların sunuluş sırasına göre değerlendirilmiştir.

Katılımcıların demografik profili Tablo-1' de gösterilmektedir.

Tablo.1: Katılımcıların Demografik Özellikleri

\begin{tabular}{|c|c|c|c|c|c|}
\hline Cinsiyet & $\mathrm{N}$ & $\begin{array}{l}\text { Geçerli } \\
\text { Yüzde (\%) }\end{array}$ & Medeni Durumu & $\mathrm{N}$ & $\begin{array}{l}\text { Geçerli } \\
\text { Yüzde (\%) }\end{array}$ \\
\hline Bay & 131 & 96.3 & Evli & 128 & 94.1 \\
\hline Bayan & 5 & 3.7 & Bekar & 8 & 5.9 \\
\hline Toplam & 136 & 100 & Toplam & 136 & 100 \\
\hline \multicolumn{3}{|l|}{ Yaş } & \multicolumn{3}{|l|}{ Kadro/Konum } \\
\hline $21-30$ & 2 & 1.5 & Memur & 31 & 22.8 \\
\hline $31-40$ & 32 & 23.5 & İşçi & 105 & 77.2 \\
\hline $41-50$ & 72 & 52.9 & Toplam & 136 & 100 \\
\hline 50 ve üstü & 30 & 22.1 & & & \\
\hline Toplam & 136 & 100 & & & \\
\hline \multicolumn{3}{|c|}{ Aylık Toplam Gelir } & \multicolumn{3}{|l|}{ Eğitim } \\
\hline $1.000 \mathrm{TL}$ den az & 0 & 0.00 & ilköğretim ve altı & 27 & 19.9 \\
\hline $1.000-1.500 \mathrm{TL}$ & 20 & 14.7 & Lise & 89 & 65.4 \\
\hline $1.501-2.000 \mathrm{TL}$ & 64 & 47.1 & Önlisans/Lisans/Yük.Lis. & 20 & 14.7 \\
\hline 2.001 ve üstü & 52 & 38.2 & Toplam & 136 & 100 \\
\hline Toplam & 136 & 100 & & & \\
\hline \multicolumn{3}{|c|}{ Mevcut İş yerindeki Çalışma Süresi } & \multicolumn{3}{|l|}{ Çalışma Şekli } \\
\hline
\end{tabular}


Uşak Üniversitesi Sosyal Bilimler Dergisi

$2013,6 / 3$

R. KILIÇ, S. Ö. SAKALLI

\begin{tabular}{|l|l|l|l|l|l|}
\hline $1-5$ yıl & 9 & 6.6 & Daimi Gündüz & 48 & 35.3 \\
6-10 y1l & 13 & 9.6 & 2 Vardiyalı & 18 & 13.2 \\
11-15 yıl & 26 & 19.1 & 3 Vardiyalı & 70 & 51.5 \\
16-20 yıl & 22 & 16.2 & Toplam & 136 & 100 \\
21 yıl ve üstü & 66 & 48.5 & & & \\
Toplam & 136 & 100 & & & \\
\hline
\end{tabular}

Araştırmada iş stresi ve iş-aile çatışması ile ilgili verilere faktör analizi uygulanmıştır.

Tablo 2: Faktör Analizi

\begin{tabular}{|c|c|c|c|}
\hline İfadeler & $\begin{array}{c}\text { Cronbach } \\
\text { Alfa }\end{array}$ & $\begin{array}{c}\text { Faktör } \\
\text { Yükü }\end{array}$ & $\begin{array}{c}\text { Açıklanan } \\
\text { Varyans(\%) }\end{array}$ \\
\hline \multicolumn{4}{|l|}{ İş yükü ile ilgili maddeler ( Faktör 3) } \\
\hline $\begin{array}{l}\text { S.1. İşimde çok hızlı çalışmak } \\
\text { zorundayım. }\end{array}$ & \multirow{5}{*}{0.885} & 0.908 & \multirow{5}{*}{11,759} \\
\hline $\begin{array}{l}\text { S.2. İşimde çok yoğun çalışmak } \\
\text { zorundayım. }\end{array}$ & & 0.880 & \\
\hline S.3. İşim çok fazla kuvvet gerektirir. & & Elendi & \\
\hline $\begin{array}{l}\text { S.4. İşimde, işimle ilgili görevleri } \\
\text { yetiştirecek kadar zamanım oluyor. }\end{array}$ & & Elendi & \\
\hline $\begin{array}{l}\text { S.5. İşimde benden birbiriyle çelişen } \\
\text { görevler istenir. }\end{array}$ & & Elendi & \\
\hline \multicolumn{4}{|c|}{$\begin{array}{l}\text { İş Kontrolü ile ilgili maddeler (Faktör 2=beceri kullanımı, Faktör 4= Karar } \\
\text { verme) }\end{array}$} \\
\hline $\begin{array}{l}\text { S.6. İşimde yeni şeyleri öğrenme } \\
\text { olasılığ } 1 \text { vardır. }\end{array}$ & \multirow{5}{*}{0.777} & 0.778 & \multirow{5}{*}{20,789} \\
\hline $\begin{array}{l}\text { S.7. İşim yüksek düzeyde beceri veya } \\
\text { uzmanlık gerektirir. }\end{array}$ & & 0.776 & \\
\hline $\begin{array}{l}\text { S.8. İşimde benden yeniliklere } \\
\text { yapmam beklenir. }\end{array}$ & & 0.779 & \\
\hline $\begin{array}{l}\text { S.9. İşimde her gün aynı şeyleri } \\
\text { yaparım. }\end{array}$ & & Elendi & \\
\hline $\begin{array}{l}\text { S.10. İşimi NASIL yapacağım } \\
\text { konusunda karar vermede benim }\end{array}$ & & 0.856 & \\
\hline
\end{tabular}




\begin{tabular}{|c|c|c|c|}
\hline seçim hakkım vardır. & & & \\
\hline $\begin{array}{l}\text { S.11. İşimde NE yapacağıma karar } \\
\text { vermede benim seçim hakkım vardır. }\end{array}$ & & 0.883 & \\
\hline \multicolumn{4}{|c|}{ Sosyal Destek ile ilgili maddeler (Faktör 1) } \\
\hline $\begin{array}{l}\text { S.12. Çalıştığım yerde sakin ve hoş bir } \\
\text { ortam vardır. }\end{array}$ & \multirow{6}{*}{0.874} & Elendi & \multirow{6}{*}{43,256} \\
\hline $\begin{array}{l}\text { S.13. Çalıştığım yerde birbirimizle iyi } \\
\text { geçiniriz. }\end{array}$ & & 0.794 & \\
\hline $\begin{array}{l}\text { S.14. İş yerinde diğer çalışanlar beni } \\
\text { destekler. }\end{array}$ & & 0.827 & \\
\hline $\begin{array}{l}\text { S.15. Kötü günümdeysem iş } \\
\text { yerindekiler durumumu anlarlar. }\end{array}$ & & 0.698 & \\
\hline S.16. Üstlerimle ilişkilerim iyidir. & & 0.743 & \\
\hline $\begin{array}{l}\text { S.17. İş arkadaşlarımla çalışmak } \\
\text { hoşuma gider. }\end{array}$ & & 0.806 & \\
\hline \multicolumn{4}{|l|}{ İş-Aile Çatışması ile ilgili maddeler } \\
\hline $\begin{array}{l}\text { S.1. İş sorumluluklarım aile ve ev } \\
\text { yaşantımı olumsuz olarak etkiliyor. }\end{array}$ & \multirow{5}{*}{0.878} & 0.895 & \multirow{5}{*}{67,532} \\
\hline $\begin{array}{l}\text { S.2. İşimin aldığı zaman aileme karşı } \\
\text { sorumluluklarımı yerine getirmemi } \\
\text { zorlaştırıyor. }\end{array}$ & & 0.866 & \\
\hline $\begin{array}{l}\text { S.3. İşimin gereksinimleri nedeniyle } \\
\text { evde yapmak istediğim şeyleri } \\
\text { yapamiyorum. }\end{array}$ & & 0.797 & \\
\hline $\begin{array}{l}\text { S.4. İşimin yarattığ } 1 \text { gerginlik ve yük } \\
\text { nedeniyle aile yaşantımla ilgili } \\
\text { yapmak istediğim şeyleri } \\
\text { yapamiyorum. }\end{array}$ & & 0.792 & \\
\hline $\begin{array}{l}\text { S.5. İş sorumluluklarım nedeniyle } \\
\text { ailemle ilgili planlarımı değiştirmek } \\
\text { zorunda kalıyorum. }\end{array}$ & & 0.750 & \\
\hline
\end{tabular}

İsveç iş yükü-kontrolü-sosyal destek ölçeğinde yer alan 17 ifadeye ilişkin faktör yükleri Tablo $2^{\prime}$ de görülmektedir. İsveç iş yükü-kontrolü-sosyal destek ölçeğinde yer alan 17 sorudan 5'i (3,4,5,9 ve 12. Madde) yapılan faktör analizi sonucunda düşük değer çıtığı için elenmiştir. İsveç iş yükü-kontrolü- 
sosyal destek ölçeğindeki 12 ifadenin önemiyle ilgili 4 faktörel boyut belirlenmiştir. Bu faktörel boyutlara ait faktör yükleri Tablo 2` de görülmektedir. Barlett testi sonucu 833.426 değeri ve $\mathrm{p}=0.000<0.05$ düzeyi ile Kaiser-MeyerOlkin örneklem değeri 0.814 olarak gerçekleşmiştir ki; bu değerler kabul edilebilir sınırlar içinde yer almaktadır (Kalaycı, 2010: 321). Verilere uygulanan temel bileşenler analizinde varimax faktör döndürme seçeneği kullanılmıştır. 12 değişkenin dört faktör altında, toplam varyansın \%75.804'ünü açıklamaktadır. Faktör 1'in tanımladığ 1 fark yüzdesi 43.256 düzeyindedir ve 5 madde ile ifade edilmektedir. Bu faktörün altında bulunan maddeler sosyal destek ile ilgili maddelerden oluşmaktadır. Faktör 2'nin tanımladığı fark yüzdesi 12.326 düzeyindedir ve 3 madde ile ifade edilmektedir. Bu faktörün altında bulunan maddeler iş kontrolünün beceri ile ilgili maddelerinden oluşmaktadır. Faktör 3'ün fark yüzdesi 11.759 düzeyindedir ve 2 madde ile ifade edilmektedir. Bu faktörün altında bulunan maddeler iş yükü ile ilgili maddelerden oluşmaktadır. Faktör 4'ün tanımladığı fark yüzdesi 8.463 düzeyindedir ve 2 madde ile ifade edilmektedir. Bu faktörün altında bulunan maddeler ise karar verme yeteneği ile ilgili maddelerden oluşmaktadır. İsveç iş yükü-kontrolü-sosyal destek ölçeğinin yapısında bulunan faktörler bu araştırmada de benzerlik göstermiştir. İş stresi ölçeğinin güvenilirliğinin (Cronbach Alfa) test edilmesi amacıyla güvenirlik analizi uygulanmıştır. İş stresi ile ilgili ölçeğin güvenilirlik analizi sonucunda verilerin (elenenler hariç) güvenilirlik değeri 0.873 olarak tespit edilmiştir. Bu sonuç iş tatmini ölçeğinin yüksek derecede güvenirliğe sahip olduğunu göstermektedir (Kalayc1, 2010:405). İş stresi ölçeğinin boyutları ile ilgili olarak her bir boyutta yer alan ölçek maddelerinin (elenenler hariç) güvenirlik analizleri yapılmıştır ve Tablo 2'de gösterilmektedir. İş stresi ölçeğinin alt boyutları ile ilgili olarak güvenilirlik değerleri de kabul edilebilir sınırlar içinde kalmaktadır (Kalaycı, 2010:405).

İş-Aile Çatışması Ölçeğinde yer alan 5 maddeye yapılan faktör analizi sonucu 1 faktörel boyut belirlenmiştir. Bu faktörel boyuta ait faktör yükleri 0.750 ile 0.895 arasındadır. Barlett testi sonucu 367.803 değeri ve $p=0.000<0.05$ düzeyi ile Kaiser-Meyer- Olkin örneklem değeri 0.820 olarak gerçekleşmiştir ki; bu değerler kabul edilebilir sınırlar içinde yer almaktadır (Kalaycı, 2010: 321). Verilere uygulanan temel bileşenler analizinde varimax faktör döndürme seçeneği kullanılmıştır. 5 değişkenin bir faktör altında, toplam varyansın \%67.532'sini açıklamaktadır. İş-Aile Çatışması ölçeğinin güvenilirliğinin 
(Cronbach Alfa) test edilmesi amacıyla güvenirlik analizi uygulanmıştır. İş-Aile Çatışması ile ilgili ölçeğin güvenilirlik analizi sonucunda verilerin güvenilirlik değeri 0.878 olarak tespit edilmiştir. Bu sonuç İş-Aile Çatışması ölçeğinin yüksek derecede güvenirliğe sahip olduğunu göstermektedir (Kalayc1, 2010:405).

Hipotez Analizlerine İlişkin Bulgular: İş-aile çatışması ve iş stresi faktörlerinin birbirleri ile olan ilişkilerini değerlendirmek amaciyla korelasyon analizi yapılmıştır. "Hipotez 1: Çalışanların iş stresi boyutları ile iş-aile çatışması arasında pozitif ve anlamlı bir ilişki vardır." Hipotezine ilişkin yapılan korelasyon analizi sonucuna göre; iş-aile çatışması ile iş stresi boyutları arasında anlamlı bir ilişki bulunmamıştır. Buna rağmen korelasyon matrisinde yer alan iş stresinin dört boyutu arasındaki ilişkiler incelendiğinde boyutlar arasında pozitif ve anlamlı ilişki olduğu görülmektedir. Faktörler arasında ilişkinin en fazla olduğu boyut sosyal destek ile beceri boyutu arasindadır $(r=0.464 ; \mathrm{p}=0.000<0.01)$. Elde edilen sonuçlara göre $\mathrm{H} 1$ hipotezi reddedilmiştir.

Tablo 3: Korelasyon Analizi Sonuçları

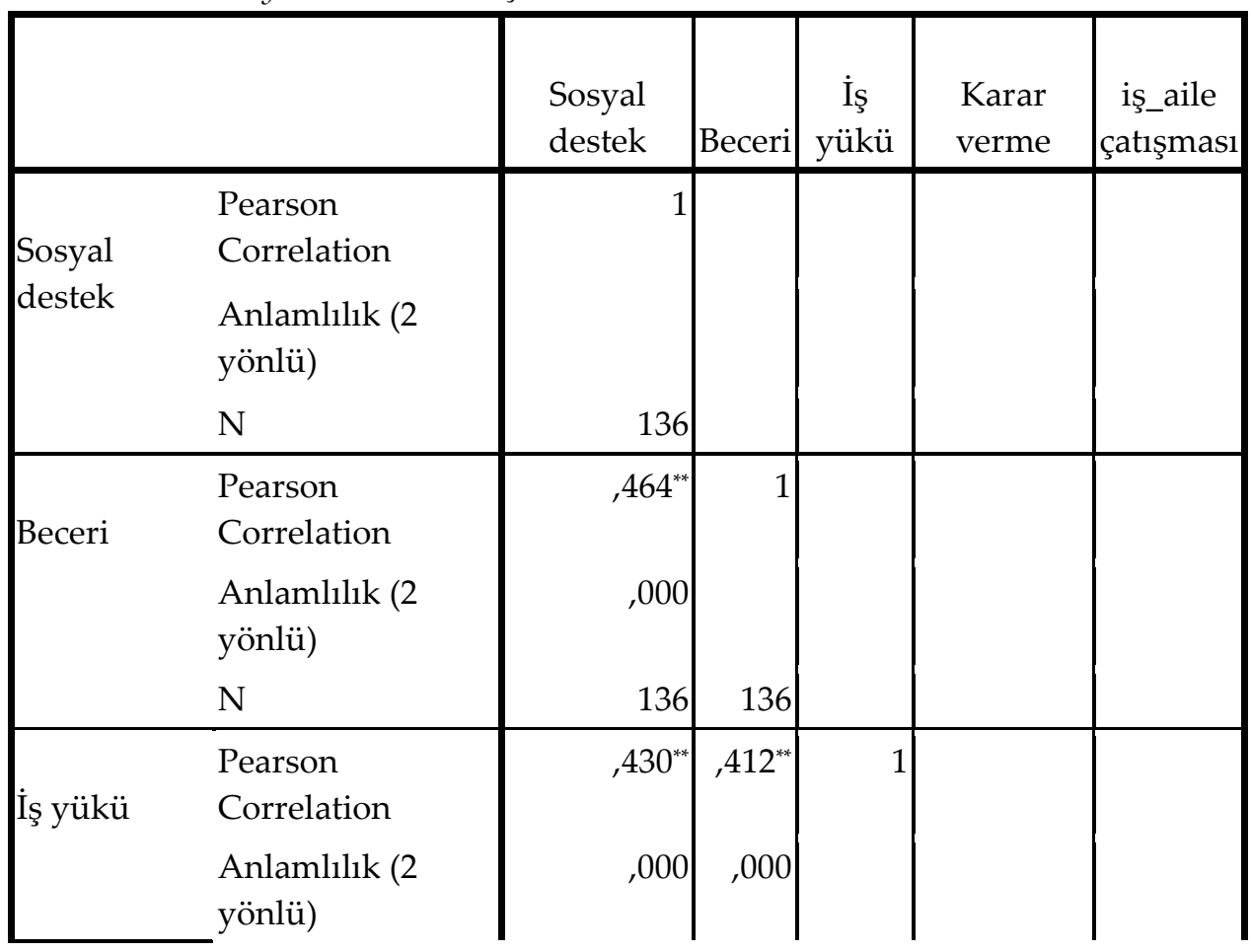


Uşak Üniversitesi Sosyal Bilimler Dergisi

\begin{tabular}{|ll|r|r|r|r|r|}
\hline & $\mathrm{N}$ & 136 & 135 & 136 & & \\
\hline \multirow{2}{*}{$\begin{array}{l}\text { Karar } \\
\text { verme }\end{array}$} & $\begin{array}{l}\text { Pearson } \\
\text { Correlation } \\
\end{array}$ &, $414^{* * *}$ &, $397^{* *}$ &, 158 & 1 & \\
& $\begin{array}{l}\text { Anlamlılık }(2 \\
\text { yönlü) }\end{array}$ &, 000 &, 000 &, 067 & & \\
& $\mathrm{~N}$ & 136 & 135 & 136 & 136 & \\
\hline $\begin{array}{l}\text { iş_aile } \\
\text { çatışmas1 }\end{array}$ & $\begin{array}{l}\text { Pearson } \\
\text { Correlation }\end{array}$ &,- 119 &, 030 &, 030 &,- 010 & 1 \\
& $\begin{array}{l}\text { Anlamlılık }(2 \\
\text { yönlü) }\end{array}$ &, 167 &, 729 &, 729 &, 911 & \\
& $\mathrm{~N}$ & 136 & 135 & 136 & 136 & 136 \\
\hline
\end{tabular}

** Korelasyon 0,01 düzeyinde çift taraflı öneme sahiptir.

$\mathrm{N}=136 \quad \mathrm{p}<0,01$

Çalışmanın bu bölümünde araştırma grubunu oluşturan personelin iş stresi ve iş-aile çatışması ölçeğinden elde ettikleri puanların sosyo-demografik (medeni durum, yaş, eğitim, gelir ve kadro/konum) değişkenlere göre anlamlı bir şekilde farklılaşıp farklılaşmadığına ve aralarındaki ilişkilere ilişkin analiz sonuçlarına yer verilmiştir.

Tablo 4: Çalışanların İş stresi faktörlerinin ve İş-Aile Çatışmasının Sosyo-demografik özelliklerine Göre Farklılaşıp Farklılaşmadı̆̆ını Belirlemek Üzere Yapılan Bağımsız Grup t test Sonuçları

\begin{tabular}{|ll|r|r|r|c|c|}
\hline & $\begin{array}{l}\text { Medeni } \\
\text { durum }\end{array}$ & $\mathrm{N}$ & Ortalama & Std. Sapma & t Değeri & $\begin{array}{c}\text { Sig. ( 2 yönlü) } \\
\text { p değeri }\end{array}$ \\
\hline Sosyal destek & evli & 128 & 3,9125 &, 85325 & .980 & .329 \\
& bekar & 8 & 3,6000 & 1,20000 & & \\
\hline Beceri & evli & 128 & 3,5286 & 1,01909 & .643 & .521 \\
& bekar & 8 & 3,2917 &, 84398 & & \\
\hline İş yükü & evli & 128 & 3,1250 & 1,27205 & .268 & .789 \\
& bekar & 8 & 3,0000 & 1,41421 & & \\
\hline
\end{tabular}


Uşak Üniversitesi Sosyal Bilimler Dergisi

$2013,6 / 3$

R. KILIÇ, S. Ö. SAKALLI

\begin{tabular}{|ll|r|r|r|c|c|}
\hline Karar verme & evli & 128 & 3,3281 & 1,10908 & -1.523 & .130 \\
& bekar & 8 & 3,9375 &, 86344 & & \\
\hline iş_aile & evli & 128 & 2,2906 & 1,00483 & -.633 & .528 \\
çatışması & bekar & 8 & 2,5250 & 1,20919 & & \\
\hline
\end{tabular}

${ }^{*} \mathrm{p}<, 05$

Tablo 4'de görüldüğü üzere, araştırma grubunu oluşturan personelin iş stresi faktörlerinin ve iş-aile çatışmasının medeni durum değişkenine göre anlamlı bir farklılık gösterip göstermediğini belirlemek amacıyla yapılan bağımsız grup t-testi sonucunda, iş stresinin dört boyutu ve iş-aile çatışması ile medeni durum değişkeni arasındaki fark istatistiksel olarak anlamlı bulunmamıştır ( $\mathrm{p}>0.05)$.

Tablo 5: İşs Stresi faktörlerinin ve İş-Aile Çatışmasının Yaş Değişkenine Göre Farklılaşıp Farklılaşmadı̆̆ını Belirlemek Üzere Yapılan Tek Yönlü Varyans Analizi (ANOVA) Sonuçları

\begin{tabular}{|c|c|c|c|c|c|c|}
\hline & & $\begin{array}{l}\text { Kareler } \\
\text { Toplamı }\end{array}$ & s.d. & $\begin{array}{c}\text { Kareler } \\
\text { Ortalaması }\end{array}$ & $\mathrm{F}$ & $\underset{\text { değeri }}{\mathrm{p}}$ \\
\hline \multirow{3}{*}{$\begin{array}{l}\text { Sosyal } \\
\text { destek }\end{array}$} & Gruplararasında & 6,521 & 3 & \multirow{3}{*}{$\begin{array}{c}2,174 \\
733\end{array}$} & \multirow[t]{3}{*}{2,965} & \multirow[t]{3}{*}{,034 } \\
\hline & Gruplariçinde & 96,755 & 132 & & & \\
\hline & Toplam & 103,275 & 135 & & & \\
\hline \multirow[t]{3}{*}{ Beceri } & Gruplararasinda & 3,313 & 3 & \multirow{3}{*}{$\begin{array}{l}1,104 \\
1,015\end{array}$} & \multirow[t]{3}{*}{1,088} & \multirow[t]{3}{*}{,357 } \\
\hline & Gruplariçinde & 133,991 & 132 & & & \\
\hline & Toplam & 137,304 & 135 & & & \\
\hline \multirow[t]{3}{*}{ İş yükü } & Gruplararasinda & 9,923 & 3 & \multirow{3}{*}{$\begin{array}{l}3,308 \\
1,589\end{array}$} & \multirow[t]{3}{*}{2,082} & \multirow[t]{3}{*}{, 106 } \\
\hline & Gruplariçinde & 209,695 & 132 & & & \\
\hline & Toplam & 219,618 & 135 & & & \\
\hline \multirow{3}{*}{$\begin{array}{l}\text { Karar } \\
\text { verme }\end{array}$} & Gruplararasinda & 5,518 & 3 & 1,839 & \multirow[t]{3}{*}{1,530} & \multirow[t]{3}{*}{,210 } \\
\hline & Gruplariçinde & 158,715 & 132 & 1,202 & & \\
\hline & Toplam & 164,233 & 135 & & & \\
\hline
\end{tabular}


Uşak Üniversitesi Sosyal Bilimler Dergisi

$2013,6 / 3$

R. KILIÇ, S. Ö. SAKALLI

\begin{tabular}{|ll|c|c|c|c|c|}
\hline iš_aile & Gruplararasında &, 654 & 3 &, 218 &, 208 &, 891 \\
çatışması & Gruplariçinde & 138,224 & 132 & 1,047 & & \\
& Toplam & 138,877 & 135 & & & \\
\hline
\end{tabular}

${ }^{*} \mathrm{p}<0.05$

ANOVA tablosu iş stresi faktörleri ile iş-aile çatışmasında yaş grupları arasında bir farklılığın olup olmadığını test etmektedir. Burada ki p değeri (Sig.) 0.05 'den büyüktür. Yani yaş grupları arasında iş-aile çatışması ve iş stresi faktörlerinde herhangi bir farklılığın olmadığı söylenebilir.

Tablo 6: Işs stresi faktörlerinin ve İş-Aile Çatışmasının Eğitim Değgişkenine Göre Farklılaşıp Farklılaşmadığını Belirlemek Üzere Yapılan Tek Yönlü Varyans Analizi (ANOVA) Sonuçları

\begin{tabular}{|ll|c|c|c|c|c|}
\hline & & $\begin{array}{r}\text { Kareler } \\
\text { Toplamı }\end{array}$ & s.d. & $\begin{array}{c}\text { Kareler } \\
\text { Ortalamas }\end{array}$ & F & $\begin{array}{c}\mathrm{p} \\
\text { değeri }\end{array}$ \\
\hline Sosyal destek & Gruplararasında &, 849 & 2 &, 424 &, 551 &, 578 \\
& Gruplariçinde & 102,427 & 133 &, 770 & & \\
& Toplam & 103,275 & 135 & & & \\
\hline Beceri & Gruplararasında &, 244 & 2 &, 122 &, 118 &, 888 \\
& Gruplariçinde & 137,060 & 133 & 1,031 & & \\
& Toplam & 137,304 & 135 & & & \\
\hline İş yükü & Gruplararasında & 5,465 & 2 & 2,732 & 1,697 &, 187 \\
& Gruplariçinde & 214,153 & 133 & 1,610 & & \\
& Toplam & 219,618 & 135 & & & \\
\hline Karar verme & Gruplararasında & 8,301 & 2 & 4,151 & 3,540 &, $032^{*}$ \\
& Gruplariçinde & 155,932 & 133 & 1,172 & & \\
& Toplam & 164,233 & 135 & & & \\
\hline iş_aile & Gruplararasında &, 949 & 2 &, 475 &, 458 &, 634 \\
çatışması & Gruplariçinde & 137,928 & 133 & 1,037 & & \\
& Toplam & 138,877 & 135 & & & \\
\hline
\end{tabular}


Uşak Üniversitesi Sosyal Bilimler Dergisi

$2013,6 / 3$

R. KILIÇ, S. Ö. SAKALLI

${ }^{*} \mathrm{p}<, 05$

Tablo 6'ye göre, eğitim değişkeni ile İşs stresinin birinci, ikinci, üçüncü faktörü ve iş-aile çatışması arasında herhangi bir farklılığın olmadığı ( $>>0.05)$ ama iş stresinin dördüncü faktörü olan karar verme başlığı ile arasında bir farklılığın olduğu $(\mathrm{p}<0.05)$ söylenebilir Hangi gruplar arasında farklılığın olduğunu Post Hoc (Tukey) testleri ile belirleyebiliriz. Tablo 7'de yanlarında asterisk $\left(^{*}\right)$ imgesi olanların ortalamaları arasında 0.05 düzeyinde anlamlı bir farkın olduğu sonucuna ulaşılır. Bu sonuçlara göre; ilköğretim ve altı mezunu olan çalışanlar, Önlisans/Lisans/yüksek Lisans çalışanlara nazaran karar verme becerileri daha azdır. Aralarındaki ortalama farkı, 0.85000'dir ve anlamlılık düzeyi ( $\mathrm{p}=0.02)$ 0.05'in altındadır.

Tablo 7: İşs stresi faktörlerinin ve İş-Aile Çatışmasının Aylık Gelire Göre Farklılaşıp Farklılaşmadığını Belirlemek Üzere Yapılan Tek Yönlü Varyans Analizi (ANOVA) Sonuçları

\begin{tabular}{|ll|c|c|c|c|c|}
\hline & & $\begin{array}{c}\text { Kareler } \\
\text { Toplamı }\end{array}$ & s.d. & $\begin{array}{c}\text { Kareler } \\
\text { Ortalaması }\end{array}$ & F & $\begin{array}{c}\text { p } \\
\text { değeri }\end{array}$ \\
\hline $\begin{array}{ll}\text { Sosyal } \\
\text { destek }\end{array}$ & Gruplararasında &, 973 & 2 &, 486 &, 632 &, 533 \\
& Gruplariçinde & 102,302 & 133 &, 769 & & \\
& Toplam & 103,275 & 135 & & & \\
\hline Beceri & Gruplararasında & 5,584 & 2 & 2,792 & 2,819 &, 063 \\
& Gruplariçinde & 131,720 & 133 &, 990 & & \\
& Toplam & 137,304 & 135 & & & \\
\hline İşyükü & Gruplararasında & 3,135 & 2 & 1,567 &, 963 &, 384 \\
& Gruplariçinde & 216,483 & 133 & 1,628 & & \\
& Toplam & 219,618 & 135 & & & \\
\hline Karar & Gruplararasında & 5,504 & 2 & 2,752 & 2,306 & \multirow{2}{*}{, 104} \\
verme & Gruplariçinde & 158,730 & 133 & 1,193 & & \\
& Toplam & 164,233 & 135 & & & \\
\hline iş_aile & Gruplararasında & 5,463 & 2 & 2,731 & 2,723 &, 069 \\
çatışmasi & Gruplariçinde & 133,415 & 133 & 1,003 & &
\end{tabular}


Uşak Üniversitesi Sosyal Bilimler Dergisi

$2013,6 / 3$

R. KILIÇ, S. Ö. SAKALLI

\begin{tabular}{|c|c|c|c|c|c|c|}
\hline & & $\begin{array}{l}\text { Kareler } \\
\text { Toplamı }\end{array}$ & s.d. & $\begin{array}{c}\text { Kareler } \\
\text { Ortalaması }\end{array}$ & $\mathrm{F}$ & $\underset{\text { değeri }}{\mathrm{p}}$ \\
\hline \multirow{3}{*}{$\begin{array}{l}\text { Sosyal } \\
\text { destek }\end{array}$} & Gruplararasinda & ,973 & 2 & \multirow{3}{*}{$\begin{array}{l}\text {,486 } \\
769\end{array}$} & \multirow[t]{3}{*}{,632 } & \multirow[t]{3}{*}{,533 } \\
\hline & Gruplariçinde & 102,302 & 133 & & & \\
\hline & Toplam & 103,275 & 135 & & & \\
\hline \multirow[t]{3}{*}{ Beceri } & Gruplararasinda & 5,584 & 2 & \multirow{3}{*}{$\begin{array}{c}2,792 \\
, 990\end{array}$} & \multirow[t]{3}{*}{2,819} & \multirow[t]{3}{*}{,063 } \\
\hline & Gruplariçinde & 131,720 & 133 & & & \\
\hline & Toplam & 137,304 & 135 & & & \\
\hline \multirow[t]{3}{*}{ İş yükü } & Gruplararasında & 3,135 & 2 & \multirow{3}{*}{$\begin{array}{l}1,567 \\
1,628\end{array}$} & \multirow[t]{3}{*}{,963 } & \multirow[t]{3}{*}{,384 } \\
\hline & Gruplariçinde & 216,483 & 133 & & & \\
\hline & Toplam & 219,618 & 135 & & & \\
\hline \multirow{3}{*}{$\begin{array}{l}\text { Karar } \\
\text { verme }\end{array}$} & Gruplararasında & 5,504 & 2 & \multirow{3}{*}{$\begin{array}{l}2,752 \\
1,193\end{array}$} & \multirow[t]{3}{*}{2,306} & \multirow[t]{3}{*}{ 104 } \\
\hline & Gruplariçinde & 158,730 & 133 & & & \\
\hline & Toplam & 164,233 & 135 & & & \\
\hline \multirow{3}{*}{$\begin{array}{l}\text { iş_aile } \\
\text { çatışması }\end{array}$} & Gruplararasında & 5,463 & 2 & \multirow{3}{*}{$\begin{array}{l}2,731 \\
1,003\end{array}$} & \multirow[t]{3}{*}{2,723} & \multirow[t]{3}{*}{,069 } \\
\hline & Gruplariçinde & 133,415 & 133 & & & \\
\hline & Toplam & 138,877 & 135 & & & \\
\hline
\end{tabular}

${ }^{*} \mathrm{p}<, 05$

Tablo 7'de ki ANOVA tablosu iş stresi faktörleri ile iş-aile çatışmasında aylık gelire göre gruplar arasında bir farklılığın olup olmadığını test etmektedir. Burada ki p değeri (Sig.) 0.05'den büyüktür. Yani aylık gelir grupları arasında işaile çatışması ve iş stresi faktörlerinde herhangi bir farklılığın olmadığı söylenebilir.

Tablo 8: İş Stresi Faktörlerinin ve İş-Aile Çatışmasının Kadro/Konum Değişkenine Göre Farklılaşıp Farklılaşmadığını Belirlemek Üzere Yapılan Bă̆ımsız Grup $t$ testi Sonuçları

\begin{tabular}{|lc|c|c|c|c|c|}
\hline & $\begin{array}{l}\text { Kadro/ } \\
\text { konum }\end{array}$ & $\mathrm{N}$ & Ortalama & Std. Sapma & $\mathrm{t}$ değeri & p değeri \\
\hline Sosyal destek & memur & 31 & 4,0129 &, 75000 & .860 & .391 \\
\hline
\end{tabular}


Uşak Üniversitesi Sosyal Bilimler Dergisi

$2013,6 / 3$

R. KILIÇ, S. Ö. SAKALLI

\begin{tabular}{|ll|c|c|c|c|c|}
\hline & işçi & 105 & 3,8590 &, 90847 & & \\
\hline Beceri & memur & 31 & 3,5699 &, 82189 & .346 & .730 \\
& işçi & 105 & 3,4984 & 1,06028 & & \\
\hline İş yükü & memur & 31 & 3,7097 & 1,10132 & 3.029 & .003 \\
& işçi & 105 & 2,9429 & 1,27535 & & \\
\hline Karar verme & memur & 31 & 4,0000 &, 40825 & 3.835 & .000 \\
& işçi & 105 & 3,1762 & 1,17256 & & \\
\hline iş_aile & memur & 31 & 2,0129 &, 73200 & -1.837 & .068 \\
çatışması & işçi & 105 & 2,3905 & 1,07144 & & \\
\hline
\end{tabular}

${ }^{*} \mathrm{p}<, 05$

Tablo 8'da görüldüğü üzere, araştırma grubunu oluşturan personelin iş stresi faktörlerinin ve iş-aile çatışmasının kadro/konum değişkenine göre anlamlı bir farklılık gösterip göstermediğini belirlemek amacıyla yapılan bağımsız grup t-testi sonucunda, kadro (iş̧̧i-memur) değişkeni ile iş stresinin üçüncü ve dördüncü boyutu arasındaki fark istatistiksel olarak anlamlı bulunmuş $(p<0.05)$, iş stresinin birinci ve ikinci boyutu ile iş-aile çatışması arasında ise anlamlı bir farklılık olmadığ 1 ( $>0.05)$ tespit edilmiştir. Buradan memurların işçilere nazaran daha fazla karar verme hakkının olduğu ve iş yükünün olduğunu söyleyebiliriz. Elde edilen sonuçlara göre Hipotez-2 kısmen desteklenmektedir.

Tablo 9: Çalışma Şekli ile İş-Aile Çatışması arasında anlamlı bir Farklılık olup olmadığını Belirlemek Üzere Yapılan Tek Yönlü Varyans Analizi (ANOVA) ve Çoklu Karşılaştırma Sonuçları

iş_aile çatışması

Tukey HSD

\begin{tabular}{|c|c|c|c|c|c|c|}
\hline \multirow[b]{2}{*}{ (I) çalışma sekli } & \multirow[b]{2}{*}{ (J) çalışma_sekli } & \multirow{2}{*}{$\begin{array}{c}\text { Anlam } \\
\text { Farklılıkları } \\
\quad(\mathrm{I}-\mathrm{J})\end{array}$} & \multirow[b]{2}{*}{$\begin{array}{l}\text { Std. } \\
\text { Hata }\end{array}$} & \multirow[b]{2}{*}{$\underset{\text { değeri }}{\mathrm{p}}$} & \multicolumn{2}{|c|}{ ANOVA } \\
\hline & & & & & $\mathrm{F}$ & $\mathrm{p}$ değeri \\
\hline
\end{tabular}




\begin{tabular}{|c|c|c|c|c|c|c|}
\hline daimi gündüz & $\begin{array}{l}\text { II vardiyalı } \\
\text { "07:30-15:30; } \\
\text { 15:30-23:30" } \\
\text { III vardiyalı " } \\
\text { 07:30-15:30; } \\
\text { 15:30-23:30; } \\
\text { 23:30-07:30" }\end{array}$ & $\begin{array}{l}-, 10833 \\
-, 45024^{*}\end{array}$ & $\begin{array}{l}, 27609 \\
, 18720\end{array}$ & ,046 & \multirow{3}{*}{3.090} & \multirow{3}{*}{$.049^{*}$} \\
\hline $\begin{array}{l}\text { II vardiyalı } \\
\text { "07:30-15:30; } \\
\text { 15:30-23:30" }\end{array}$ & $\begin{array}{l}\text { daimi gündüz } \\
\text { III vardiyalı " } \\
\text { 07:30-15:30; } \\
\text { 15:30-23:30; } \\
\text { 23:30-07:30" }\end{array}$ & $\begin{array}{c}\text {,10833 } \\
-, 34190\end{array}$ & $\begin{array}{l}27609 \\
26399\end{array}$ & $\begin{array}{l}919 \\
400\end{array}$ & & \\
\hline $\begin{array}{l}\text { III vardiyalı } \\
\text { " 07:30-15:30; } \\
\text { 15:30-23:30; } \\
\text { 23:30-07:30" }\end{array}$ & $\begin{array}{l}\text { daimi gündüz } \\
\text { II vardiyalı } \\
\text { "07:30-15:30; } \\
\text { 15:30-23:30" }\end{array}$ & $\begin{array}{r}, 45024^{*} \\
34190\end{array}$ & $\begin{array}{l}18720 \\
26399\end{array}$ & $\begin{array}{l}, 046^{*} \\
400\end{array}$ & & \\
\hline
\end{tabular}

*Anlam farklılıkları \%5 seviyesinde önemlidir.

Tablo 9'a göre, çalışma şekli ile İş-aile çatışması arasında farklılığın olduğu $(\mathrm{p}<0.05)$ söylenebilir. Hangi gruplar arasında farklılığın olduğunu Post Hoc (Tukey) testleri ile belirleyebiliriz. Tablo 9' da yanlarında asterisk (*) imgesi olanların ortalamaları arasında 0.05 düzeyinde anlamlı bir farkın olduğu sonucuna ulaşılır. Bu sonuçlara göre; üç vardiyalı çalışanlar daimi gündüz çalışanlara göre daha fazla iş-aile çatışması yaşamaktadır. Bunun nedenini vardiyalı çalışanların çalışma saatlerinin sürekli değişmesi şeklinde yorumlayabiliriz. Aralarındaki ortalama fark 0.45024 'dür ve anlamlılık düzeyi ( $\mathrm{p}=0.046$ ) 0.05 'in altındadır. Elde edilen sonuçlara göre, "Hipotez 3: Çalışma şekli ile iş-aile çatışması arasında anlamlı bir farklılık vardır." yeterli kanıtla desteklenmiştir. Ortaya çıkan sonuç benzer araştırmalarda da görülmektedir (Carlson vd., 1995: 18; Karatepe ve Baddar, 2006).

İş stresi faktörlerinin iş-aile çatışmasına olan etkilerini belirlemek amacıyla Çoklu Doğrusal Regresyon analizleri yapılmıştır. 
Uşak Üniversitesi Sosyal Bilimler Dergisi

$2013,6 / 3$

R. KILIÇ, S. Ö. SAKALLI

Tablo 10: Model Özetib

\begin{tabular}{|c|c|c|c|c|c|}
\hline Model & $\mathrm{R}$ & $\mathrm{R}^{2}$ & $\begin{array}{c}\text { Düzeltilmiş } \\
\mathrm{R}^{2}\end{array}$ & $\begin{array}{c}\text { Tahmini Std. } \\
\text { Hata }\end{array}$ & Durbin-Watson \\
\hline 1 &, $165^{\mathrm{a}}$ &, 027 &,- 002 & 1,01551 & 1,740 \\
\hline
\end{tabular}

a. Belirleyiciler: (Sabit), karar verme, iş yükü, beceri, sosyal destek

b. Bağımlı değişken: iş-aile çatışması

Buradan; "Hipotez 4: Çalışanların iş stresi düzeyleri arttıkça iş-aile çatışması da artmaktadır." Hipotezine ilişkin yapılan regresyon analizi sonucuna göre; işaile çatışmasının \% 2.7'si iş stresi faktörlerinin dört boyutu tarafından açıklanmaktadır $\left(R^{2}=0.027\right.$, Düzeltilmiş $\left.R^{2}=-0.002\right)$. Yine tablo da önemli bir test de Durbin-Watson testidir. Modelimizde otokorelasyon olup olmadiğını gösterir. Değer 0 ile 4 arasında değişir. 0' a yakın değerler aşırı pozitif korelasyonu, 4'e yakın değerler aşırı negatif korelasyonu, 2'ye yakın olan değerler otokorelasyon olmadığını gösterir. Durbin-Watson değerinin 1.5 ile 2.5 arasında olması arzulanır (Kalaycı, 2010: 264).

Tablo 11: ANOVA $^{b}$

\begin{tabular}{|c|c|c|c|c|c|c|}
\hline \multicolumn{2}{|c|}{ Model } & Kareler Toplamı & s.d. & Kareler Ortalaması & $\mathrm{F}$ & $\begin{array}{c}\text { Sig. } \\
\text { p değeri }\end{array}$ \\
\hline \multirow[t]{3}{*}{1} & Regresyon & 3,782 & 4 & 945 & 917 & $456^{\mathrm{a}}$ \\
\hline & $\begin{array}{l}\text { Artık( } \\
\text { Kalıntı) }\end{array}$ & 135,095 & 131 & 1,031 & & \\
\hline & Toplam & 138,877 & 135 & & & \\
\hline
\end{tabular}

a. Belirleyiciler: (Sabit),karar verme, iş yükü, beceri, sosyal destek

b. Bağımlı değişken: iş-aile çatışması

ANOVA tablosu modelimizin bir bütün olarak anlamlı olup olmadığını test etmemize yarar. Tablo $11^{\prime}$ de ki $p=0,456>0,05$ olduğundan dolay 1 modelimizin bir bütün olarak her düzeyde anlamlı olmadığını gösterir.

Tablo 12: Katsayılar Tablosu $u^{\underline{a}}$

\begin{tabular}{|l|c|c|c|c|}
\hline Model & $\begin{array}{c}\text { Standartlaştırılmamış } \\
\text { katsayı }\end{array}$ & $\begin{array}{c}\text { Standartlaştırılmış } \\
\text { katsayı }\end{array}$ & $\mathrm{t}$ & $\begin{array}{c}\text { Sig. } \\
\text { p değeri }\end{array}$ \\
\hline
\end{tabular}




\begin{tabular}{|c|c|c|c|c|c|c|}
\hline & & B & Std. Hata & Beta & & \\
\hline \multirow[t]{5}{*}{1} & (Sabit) & 2,662 & ,431 & & 6,173 & ,000 \\
\hline & $\begin{array}{l}\text { Sosyal } \\
\text { destek }\end{array}$ &,- 231 & 124 & -,199 & $-1,867$ & ,064 \\
\hline & Beceri & ,066 & 105 & ,065 & 623 & ,534 \\
\hline & İş yükü & ,067 & ,079 &, 084 & 846 & ,399 \\
\hline & $\begin{array}{l}\text { Karar } \\
\text { verme }\end{array}$ & ,031 & ,090 &, 034 & 343 & 732 \\
\hline
\end{tabular}

a- Bağımlı değişken: İ̧s-aile çatışması

Tablo 12'de modelin tahmini sonucu elde edilen parametre değerleri ve bunlara ilişkin $t$ değerleri gösterilmektedir. Tablodan görüleceği gibi sabit terim 2,662 olarak bulunmuştur. Bunun anlamı iş stresi faktörünün boyutlarının her bir maddesi sıfır bile olsa çalışanların çalıştıkları kurumda 2,662 birimlik bir işaile çatışması yaşamaktadır. Sosyal destek'e ait parametre değeri -.231' dir. Yani sosyal destekte ki bir birimlik artış iş-aile çatışmasını .231 birim azaltmaktadır. Diğer faktörlerde ki bir birimlik artış ise sırasıyla iş-aile çatışmasını $ß=, 066, \beta=$ ,067, $B=$,031 birim artırmaktadır. Tabloda standartlaştırılmış katsayı başlığı altında yer alan Beta, bağımsız değişkenlerin önem sırasını gösterir. (Betanın işaretini dikkate almayınız.) En yüksek beta değerine sahip olan değişken, göreli olarak en önemli bağımsız değişkendir (Kalaycı, 2010:269). Bu çalışmada da en önemli bağımsız değişkenin sosyal destek $(\Omega=-0.231, p=0.064>0.05)$ olduğunu görüyoruz. Burada ki çalışmada her bir bağımsız değişkenin p değeri 0,05 den büyük olduğu için regresyon sonuçları anlamlı bulunamamıştır. Elde edilen sonuçlara göre $\mathrm{H} 4$ hipotezi yeterli kanıtla desteklenmemiştir.

\section{5- SONUÇ VE ÖNERILER}

Günümüzde birey, iş, aile ve sosyal çevre arasındaki üçgende yaşantısını sürdürmekte ve bu üç unsurun oluşturduğu stres kaynakları ile mücadelesini sürdürmektedir. Çalışanların iş-aile çatışması düzeylerini yönetebilmek için kişisel çaba göstermelerinin gerekliliği tartışılmaz olmakla birlikte, işletmelerin de çalışanlarının iş-aile çatışması düzeylerini yönetme amacı güden programlar 
geliştirmelerinin gerekliliği göz ardı edilmemelidir. İşletme yöneticilerinin, özellikler de insan kaynakları uzmanlarının, çalışanların iş-aile çatışması düzeylerini yönetebilmeleri, çatışmanın olumsuz etkilerini ortadan kaldırabilmeleri büyük önem taşımaktadır. Bu çalışmada yönetim ve organizasyon bakış açısı benimsenmekle birlikte, farklı disiplinlerden çalışmacıların gerçekleştirdikleri araştırmaların bulguları da dikkate alınarak iş stresinin, çalışanların iş-aile çatışmasına olan etkisinin incelenmesi amaçlanmıştır. Bu bağlamda çalışmanın hazırlanması aşamasında öncelikle araştırma konusu olan iş yerindeki stres, stres kaynakları ile iş-aile çatışması kavramı ve arasında ne tür ilişkiler olduğunu belirlemek amacıyla literatür incelemesi gerçekleşmiştir.

İş stresi faktörleri ile iş-aile çatışması arasında düşük ve negatif, iş stresi faktörleri arasında ise pozitif ve anlamlı bir ilişki bulunmaktadır. İş stresinin faktörleri ile ilişkinin en fazla olduğu maddeler sosyal destekler ilgili maddelerdir; "Çalıştığım yerde birbirimizle iyi geçiniriz.", "İş yerinde diğer çalışanlar beni destekler.", "Kötü günümdeysem iş yerindekiler durumumu anlarlar.", "Üstlerimle ilişkilerim iyidir.", "İş arkadaşlarımla çalışmak hoşuma gider." Sonuçlara bakıldığında çalışanların iş ortamında iş stresi faktörlerinden biri olan sosyal desteğin sağlandığı yani ast- üst ilişkilerinin ve çalışma arkadaşları ile ilişkilerin iyi olduğu görülmektedir. Bununla birlikte çalışanların, iş stresi faktörlerinden olan iş yükü, beceri kullanımı ve karar verme hakkı gibi konularda genel ortalamanın(3.59) altında bir puan aldığı görülmektedir. İş stresi faktör boyutları arasında en düşük ortalamanın iş yükü (3.12) boyutunda yer alması çalışanların işlerinde hızlı ve yoğun çalışmak gerektiği konusunda kararsız olduğunu ortaya çıkarmıştır. Şeker pancarı işleme süresinde yoğun ve hızlı çalışmak gerektiğinden çalışanların fazla iş yüküyle karşılaştıkları bir gerçektir. Bu bakımdan ulaşılan sonuç, beklenebilecek bir sonuçtur. Aşırı iş yükü konusunda çalışan sayısı arttırılarak veya otomasyon sisteme geçilerek bu yoğunluğun azaltılması sağlanabilir.

Ankete katılanların iş sorumluluklarının iş-aile çatışmasına olumsuz bir etkisi olmadığı görülmektedir. Buradan çalışanların yaptıkları işten memnun olduğu, iş yükümlülüklerinin aile ve ev yaşantısını olumsuz bir şekilde etkilemediği ve çalışanların iş-aile çatışması yaşamadığı görülmektedir. Ancak 
çalışma süreleri açısından üç vardiyalı çalışanların daimi gündüz çalışanlara göre iş-aile çatışması yaşadığı görülmektedir.

Örgütlerde stres kaynaklarının çalışanların iş-aile çatışması ve iş stresi faktörleri arasında üzerindeki etkisinin sosyo-demografik değişkenlere göre farklılaşıp-farklılaşmadığını ölçmek amacıyla yapılan t testi ve varyans analizi sonuçlarına göre; yaş, medeni durum, aylık gelirden etkilenmeksizin örgütsel stres kaynakları nedeniyle iş-aile çatışması yaşamamaktadırlar. Eğitim değişkeni açısından ilköğretim mezunları Lisans ve üstü mezunlara nazaran daha az karar verme hakkında sahiptir. Kadro/ konum değişkeni açısından da memurların işçilere nazaran daha fazla karar alma hakkının ve iş yükünün olduğunu söyleyebiliriz. Bunun sebebini de Lisans ve üstü mezunlarının kurumda memur kadrosunda ve yönetim kademesinde yer alması bu nedenle de nedeniyle karar alma mekanizmasına dahil olduğunu söyleyebiliriz. Demografik özelliklerden eğitim değişkeni ile kadro/konum değişkeni arasında iş-aile çatışması yönünden herhangi bir farklılık olmadığı görülmüştür.

Tüm bu sonuçlar dikkate alındığında kurumda çalışanların yaptıkları işten tatmin olduğunu, özellikle de bireyler arasındaki etkileşimden çalışanların memnun olduğunu ve iş stresi faktörlerinin iş-aile çatışmasına sebep olmadığını söyleyebiliriz.

\section{Kaynakça}

Akgündüz, S. (2006). Örgütsel Stres Kaynaklarının Çalışanların İş Tatmini Üzerindeki Etkisi ve Banka Çalışanları için Yapılan Bir Araştırma. Yüksek Lisans Tezi, Dokuz Eylül Üniversitesi, Sosyal Bilimler Enstitüsü.

Altunışık, R., Coşkun, R., Bayraktaroğlu, S., Yıldırım, E. (2010). Sosyal Bilimlerde Araştırma Yöntemleri SPSS Uygulamalı (6. Baskı). Sakarya: Sakarya Yayıncilık.

Baltaş, A. ve Baltaş, Z. (1990). Stres ve Başa Çıkma Yollar (10.Basım). İstanbul: Remzi Kitabevi.

Baltaş, A. ve Baltaş, Z. (2000). Beden Dili, İstanbul: Remzi Kitapevi. 
Uşak Üniversitesi Sosyal Bilimler Dergisi

$2013,6 / 3$

R. KILIÇ, S. Ö. SAKALLI

Baltaş, Z. (2002). Verimli İş Hayatının Sırrı: Stres (2. Basım). İstanbul: Remzi Kitabevi.

Barutçugil, İ. (2002). Organizasyonlarda Duyguların Yönetimi (1. Baskı), İstanbul: Kariyer Yayıncilık.

Bingöl, D. ve Naktıyok, A. (2001). Yönetici Akademisyenlerin Temel Stres Kaynakları ve Stresle Mücadele Teknikleri. 9. Ulusal Yönetim ve Organizasyon Kongresi Bildiriler, s.323-336.

Bratton, J. \& Gold, J. (1999). Human Resource Managament Theory And Practice, Macmillan Press, London.

Burke, R.J. (1986). Occupational and Life Stress and the Family: Conceptual Frameworks and Research Findings. International Review of Applied Psychology. 35(3), 347-368.

Carlson, D. S., Kacmar, K. M. \& Stepina, L. P. (1995). An Examination of Two Aspects of Work-Family Conflict: Time and Identity, Women in Management Review, 10( 2), 17-25.

Çetinkaya, F. (2011). Örgütlerde Stres Kaynaklarının Çalışanların İş-Aile Çatışması Üzerindeki Etkisi ve Afyon İl Merkezindeki Bayan Banka Çalışanları Üzerine Bir Araştırma. Yüksek Lisans Tezi, Afyon Kocatepe Üniversitesi Sosyal Bilimler Enstitüsü.

Demiral, Y., Ünal, B., Kılıç, B., Soysal, A., Bilgin, A. C., Uçku, R. ve Theorell, T. (2007). İş Stresi Ölçeğinin İzmir Konak Belediyesi'nde Çalışan Erkek İşçilerde Geçerlik ve Güvenilirliğinin İncelenmesi. Toplum Hekimliği Bülteni, 26 (1), 11-18.

Dinçer, Ö. (1994). Örgüt Geliştirme. İstanbul: İz Yayıncılık.

Dubrin, A. J. (1997). Fundamentals of Organizational Behavior. Cincinnati, Ohio:South-Western College Publishing. 
Uşak Üniversitesi Sosyal Bilimler Dergisi

$2013,6 / 3$

R. KILIÇ, S. Ö. SAKALLI

Efeoğlu, İ.E. (2006). İş-Aile Yaşam Çatışmasının İş Stresi, İş Doyumu ve Örgütsel Bağl1lık Üzerindeki Etkileri: İlaç Sektöründe Bir Araştırma. Doktora Tezi, Çukurova Üniversitesi Sosyal Bilimler Enstitüsü.

Erdoğan, İ. (1999). İşletme Yönetiminde Örgütsel Davranış. İ.Ü. İşletme Fak.Yayınları No: 3, İstanbul.

Eren, E. (1998). Örgütsel Davranış ve Yönetim Psikolojisi. İstanbul: Beta Yayınevi.

Ertekin, Y. (1993). Stres ve Yönetim (Yayın No:253). Ankara: TODAİE Yayınları.

Frone, M. R. \& Cooper, M. L. (1992). Prevalence of Work-Family Conflict: Are Work and Family Boundraies Asymmetrically Permeable?. Journal of Organizational Behavior, 13(7),723-729.

Gökdeniz, İ. (2005). Üretim Sektöründeki İşletmelerin Örgüt İçi Stres Kaynakları ve Mobilyacılık Sektöründe Bir Uygulama. S.Ü. S.B.E. Dergisi. Sayı:13, ISNN 1302-1796.

Greenhaus, J. H. \& Beutell, N. J. (1985). Sources of Conflict Between Work and Family Roles. Academy of Management Review, 10(1),76-88.

Gutek, B., Searle, S. \& Klepa, L. (1991). Rational versus Gender RoleExplanations for Work-Family Conflict. Journal of Applied Psychology, 76, 560-568.

Güçlü, N. (2001). Stres Yönetimi. Gazi Üniversitesi Gazi Ĕ̆itim Fakültesi Dergisi, 21(1), 91-109.

Hughes, B. \& Boothroyd R. (2002). Günlük Hayatın Stresine Son. (Çev. Selami Koçak). İstanbul: Doruk Yayımcılık.

Işıkhan, V. (2001). Çalısma Hayatında Stres Olgusu ve Başa Çıkma Yolları. İşveren Dergisi, 39(19), 27-30. 
Uşak Üniversitesi Sosyal Bilimler Dergisi

$2013,6 / 3$

R. KILIÇ, S. Ö. SAKALLI

Kalaycı, Ş. (2010). SPSS Uygulamah Çok Değişkenli İstatistik Teknikleri (5. Baskı). Ankara: Asil Yayın Dağıtım.

Karasek, R. A. (1979). Job Demands, Job Decision Latitude, and Mental Strain: Implications for Job Redesign. Administrative Science Quarterly, 24, 285308.

Karatepe, O.M. ve Baddar, L. (2006). An Emprical Study of the Selected Consequences of Frontline Employees' Work-Family Conflict and Family- Work Conflict. Tourism Management, 27(5), 1017-1028.

Kinnunen, U., Geurts, S. \& Mauno, S. (2004). Work-to-Family Conflict and Its Relationship With Satisfaction and Well-Being: A One-Year Longitudinal Study on Gender Differences. Work \& Stres, 18 (1), 1-22.

Leiter, M.P. \& Durup, M.J. (1996). Work, Home and In-Between: A Longitudinal Study of Spillover. Journal of Applied Behavioral Science, 32(1), 29-47.

Losyk, B. (2006). Sakin Ol Sinirlerine Hâkim Ol (Çev. G. Engin). İstanbul: Acar Basımevi.

Luthans, F. (1992). Organizational Behavior. New York: Mc Graw Hill Company.

Netemeyer, R.G., Boles, J.S. \& Mcmurrian, R. (1996). Development and Validation of Work- Family Conflict and Family-Work Conflict Scales. Journal of Applied Psychology, 81, 400-410.

Netenmeyer, R.G., Alejandro, T. B. \& Boles, J.S. (2004). A Cross-National Model of Job-Related Outcomes of Work Role and Family Role Variables: A Retail Sales Context. Journal of the Academy of Marketing Science, 32(1), 4960 .

Örücü, E. ve Demir, B. (1999). Banka Çalışanlarında İş Stresi ve Muğla ili Örneği. Atatürk Üniversitesi İktisadi ve İdari Bilimler Fakültesi Dergisi, 13(1), 59. 
Uşak Üniversitesi Sosyal Bilimler Dergisi

$2013,6 / 3$

R. KILIÇ, S. Ö. SAKALLI

Özmutaf, N. M. (2006). Örgütlerde İnsan Kaynakları ve Stres : Ampirik Bir Yaklaşım. E.Ü. Su Ürünleri Dergisi, 23(1), 75-81.

Pehlivan, İ. (2000). İş Yaşamında Stres. Ankara: Pegem Yayınları.

Soysal, A. (2009). Farklı Sektörlerde Çalışan İşgörenlerde Örgütsel Stres Kaynakları: Kahramanmaraş ve Gaziantep"ete Bir Araştırma. Süleyman Demirel Üniversitesi İktisadi ve İdari Bilimler Fakültesi Dergisi, 14 (2), 333359.

Taşlıyan, M. ve Güven, M. (2006). Stres ve Yönetimi, Çağdaş Yönetim Araçlarından Seçmeler, (Edit: M. Şerif Şimşek-Said Kıngır), Ankara : Nobel Yayın.

Torun, A.(1997). Stres ve Tükenmişlik (2. Bask1). Endüstri ve Örgüt Psikolojisi içinde (Ed. Suna Tevrüz). Ankara: Türk Psikologlar Derneği Yayınları , s. $43-53$.

Turgut, T. (2011). Çalışmaya Tutkunluk: İş Yükü, Esnek Çalışma Saatleri, Yönetici Desteği ve İş-Aile Çatışması İle İlişkileri. Atatürk Üniversitesi İktisadi ve İdari Bilimler Dergisi, Cilt: 25(3), 155-179.

Turunç, Ö. ve Çelik, M. (2010). Algılanan Örgütsel Desteğin Çalışanların İş-Aile, Aile-İş Çatışması, Örgütsel Özdeşleşme ve İşten Ayrılma Niyetine Etkisi: Savunma Sektöründe Bir Araştırma. Atatürk Üniversitesi Sosyal Bilimler Enstitüsü Dergisi, 14 (1), 209-232.

Turunç, Ö. Ve Erkuş, A. (2011). İş-Aile Yaşam Çatışmasının İş Tatmini ve Örgütsel Bağlılık Üzerine Etkileri: İş Stresinin Aracılık Rolü. SÜ İ̈BF Sosyal ve Ekonomik Araştırmalar Dergisi, 13(19), 415-440.

Vinocur, A. D., Pierce, P.F. \& Buck, C.L. (1999). Work-Family Conflicts of Women in the Air Force: Their Influence on Mental Health and Functioning. Journal of Organizational Behavior, 20(6), 865-878. 
Uşak Üniversitesi Sosyal Bilimler Dergisi

$2013,6 / 3$

R. KILIÇ, S. Ö. SAKALLI

Voydanoff, P. (2005). Consequences of Boundary-Spanning Demands and Resources for Work-to-Family Conflict and Perceived Stres. Journal of Occupational Health Psychology, 10(4), 491-503.

Wallace, J. E. (1999). Work-to-Nonwork Conflict Among Married Male and Female Lawyers. Journal of Organizational Behavior, 20( 6), 797-816.

Wallace, J. E. (2005). Job Stress, Depression and Work-to-Family Conflict: A Test of the Strain and Buffer Hypotheses. Industrial Relations, 60(3), 510-539.

Yurtseven, Ö. (2008). İş-Aile Çatışması, İş Tatmini ve İşten Ayrılma Niyeti ilişkisi: Turizm işletmesinde Bir Uygulama. Yüksek Lisans Tezi, Akdeniz Üniversitesi Sosyal Bilimler Enstitüsü. 